JEL Classification: G 220

\title{
АНАЛІЗ РИНКУ СТРАХОВИХ ПОСЛУГ УКРАЇНИ
}

Онісіфорова В.Ю., канд. екон. наук, доцент

Харківський національний автомобільно-дорожній університет

Болотова Т.М., канд. екон. наук, доцент

Харківський торговельно-економічний коледж КНТЕУ

Остапенко Л.О., студент

Харківський національний автомобільно-дорожній університет

Постановка проблеми. Ринок страхових послуг в Україні характеризується високим рівнем конкуренції, однак перед компаніями, що створюються, а також перед існуючими страховими компаніями, не зважаючи на це, стоїть задача поширення масштабів діяльності шляхом виходу на нові ринки, а також на нові види страхування.

Аналіз останніх досліджень та публікацій. Дослідженню страхування присвячує свої роботи значна кількість науковців, серед яких Базилевич В.Д., Приказюк Н.В., Любашенко І., Ротова Т., Фисун В. І., Прилипко С. М., Білик О. I., Качмарчик С. А. [1-8] та інш. Однак більшість дослідників зосереджує свою увагу на теоретичних аспектах страхової діяльності та дослідженні окремих видів страхування.

Невирішені складові загальної проблеми. Не зважаючи на велику кількість досліджень вимагає перманентного розгляду проблема визначення перспективних напрямків розвитку страхового ринку України.

Формулювання цілей статті. Метою статті є визначення основних характеристик ринку кожного 3 класичних видів страхування в сучасних умовах.

Виклад основного матеріалу дослідження. Ринок страхування в Україні на сучасному етапі характеризується значною динамічністю і розширенням переліку страхових послуг з числа добровільних видів страхування, однак одночасно склалися і певні характерні риси, які визначають перспективи 
виходу страхової компанії на нові ринки при розширенні обсягів діяльності або створенні нової. Основні закономірності функціонування страхового ринку України можна побачити після проведення грунтовного аналізу показників галузі за головними найпоширенішими видами страхування, визначальними серед яких є обсяги страхових премій та обсяги страхових виплат конкретних компаній. Проведемо аналіз зазначених показників за кожним видом страхування окремо.

Таблиця 1

Аналіз обсягів страхових премій компаній від обов'язкового страхування цивільно-правової відповідальності власників наземних транспортних засобів

\begin{tabular}{|c|c|c|c|c|c|c|c|c|}
\hline \multirow{2}{*}{$\begin{array}{c}\text { Назва } \\
\text { страхової } \\
\text { компанії }\end{array}$} & \multicolumn{2}{|c|}{2015 рік } & \multicolumn{2}{|c|}{2016 рік } & \multicolumn{2}{c|}{2017 рік } & \multicolumn{2}{c|}{$\begin{array}{c}2018 \text { рік } \\
\text { (прогноз }\end{array}$} \\
\cline { 2 - 10 } & тис. грн. & $\%$ & тис. грн. & $\%$ & тис. грн. & $\%$ & тис. грн. & $\%$ \\
\hline Оранта & 265494 & 17,88 & 282000 & 16,41 & 339864 & 17,64 & 461432 & 20,16 \\
\hline Провідна & 242588 & 16,34 & 264085 & 15,36 & 268018 & 13,91 & 232548 & 10,16 \\
\hline ТАС СГ & 171740 & 11,57 & 207787 & 12,09 & 290335 & 15,07 & 438986 & 19,18 \\
\hline UРSК & 163894 & 11,04 & 184583 & 10,74 & 189581 & 9,84 & 224688 & 9,82 \\
\hline Уніка & 157077 & 10,58 & 166946 & 9,71 & 162468 & 8,43 & 182838 & 7,99 \\
\hline Княжа & 142420 & 9,59 & 159648 & 9,29 & 188620 & 9,79 & 209192 & 9,14 \\
\hline $\begin{array}{c}\text { АХА } \\
\text { страхування }\end{array}$ & 107518 & 7,24 & 139133 & 8,09 & 143186 & 7,43 & 132650 & 5,80 \\
\hline РZU Україна & 89535 & 6,03 & 127371 & 7,41 & 171777 & 8,92 & 211994 & 9,26 \\
\hline $\begin{array}{c}\text { Альфа- } \\
\text { Гарант }\end{array}$ & 72914 & 4,91 & 99386 & 5,78 & 86688 & 4,50 & 113984 & 4,98 \\
\hline Країна & 71324 & 4,80 & 87994 & 5,12 & 85882 & 4,46 & 80668 & 3,52 \\
\hline ВУСО & 58718 & 3,96 & 103125 & 6,00 & 120277 & 6,24 & 150322 & 6,57 \\
\hline Загалом & 1484506 & 100 & 1718933 & 100 & 1926421 & 100 & 2288980 & 100 \\
\hline
\end{tabular}

Складено авторами на основі [9]

Як бачимо з табл. 1, ринок так званої «автоцивілки» характеризується позитивною динамікою обсягів зібраних страхових премій, однак на ринку є група компаній, які є утримувачами переважного сегменту даного ринку, i протягом досліджуваного періоду 2015-2018 років ці компанії лише укріплюють своє положення на ринку. Такими компаніями є Оранта, Провідна, TAC СГ, UPSK. Проаналізуємо показники ринку страхування транспортних засобів від певних видів збитків (КАСКО). 


\section{Аналіз обсягів страхових премій компаній від обов'язкового}

\section{страхування транспортних засобів від певних видів збитків (КАСКО)}

\begin{tabular}{|c|c|c|c|c|c|c|c|c|}
\hline \multirow{2}{*}{$\begin{array}{c}\text { Назва } \\
\text { страхової } \\
\text { компанії }\end{array}$} & \multicolumn{2}{|c|}{2015 рік } & \multicolumn{2}{|c|}{2016 рік } & \multicolumn{2}{|c|}{2017 рік } & \multicolumn{2}{c|}{$\begin{array}{c}2018 \text { рік } \\
\text { (прогноз) }\end{array}$} \\
\cline { 2 - 9 } & тис. грн. & $\%$ & тис. грн. & $\%$ & тис. грн. & $\%$ & тис. грн. & $\%$ \\
\hline $\begin{array}{c}\text { АХА } \\
\text { страхування }\end{array}$ & 698774 & 27,30 & 858086 & 27,72 & 1006865 & 27,57 & 1045412 & 25,62 \\
\hline $\begin{array}{c}\text { Українська } \\
\text { страхова } \\
\text { група }\end{array}$ & 416507 & 16,27 & 449053 & 14,51 & 487216 & 13,34 & 514608 & 12,61 \\
\hline Уніка & 415396 & 16,23 & 486221 & 15,71 & 599029 & 16,40 & 692442 & 16,97 \\
\hline Інго-Україна & 256170 & 10,01 & 301421 & 9,74 & 328442 & 8,99 & 359122 & 8,80 \\
\hline $\begin{array}{c}\text { Арсенал } \\
\text { страхування }\end{array}$ & 198191 & 7,74 & 340729 & 11,01 & 451428 & 12,36 & 573502 & 14,06 \\
\hline РZU Україна & 174766 & 6,83 & 218414 & 7,06 & 279452 & 7,65 & 328470 & 8,05 \\
\hline Універсальна & 137324 & 5,36 & 160057 & 5,17 & 207198 & 5,67 & 271694 & 6,66 \\
\hline Провідна & 97501 & 3,81 & 103513 & 3,34 & 97404 & 2,67 & 83988 & 2,06 \\
\hline $\begin{array}{c}\text { Колоннейд } \\
\text { Україна }\end{array}$ & 83694 & 3,27 & 85867 & 2,77 & 86754 & 2,38 & 83448 & 2,05 \\
\hline Княжа & 81603 & 3,19 & 92312 & 2,98 & 108257 & 2,96 & 127490 & 3,12 \\
\hline ТАС СГ & 78770 & 3,08 & 114054 & 3,68 & 168678 & 4,62 & 209166 & 5,13 \\
\hline ВУСО & 64454 & 2,52 & 77947 & 2,52 & 119263 & 3,27 & 163470 & 4,01 \\
\hline $\begin{array}{c}\text { Експрес } \\
\text { страхування }\end{array}$ & 56849 & 2,22 & 92646 & 2,99 & 166398 & 4,56 & 190300 & 4,66 \\
\hline Загалом & 2559925 & 100 & 3095673 & 100 & 3652044 & 100 & 4080176 & 100 \\
\hline
\end{tabular}

Складено авторами на основі [9]

Як бачимо за даними табл. 2, ринок КАСКО є ще більш утримуваним певним колом компаній-лідерів, ніж ринок «автоцивілки».

За даними усього досліджуваного періоду можна виділити три страхових компанії, які фактично утримують даний ринок - це АХА страхування, Уніка, Українська страхова група, а також останніми роками укріплює свої позиції на ринку КАСКО компанія Арсенал страхування.

Проаналізуємо ринок добровільного страхування майна (табл. 3). 
Таблиия 3

Аналіз обсягів страхових премій компаній від добровільного страхування майна

\begin{tabular}{|c|c|c|c|c|c|c|c|c|}
\hline \multirow{2}{*}{$\begin{array}{c}\text { Назва } \\
\text { страхової } \\
\text { компанії }\end{array}$} & \multicolumn{2}{|c|}{2015 рік } & \multicolumn{2}{|c|}{2016 рік } & \multicolumn{2}{|c|}{2017 рік } & \multicolumn{2}{|c|}{$\begin{array}{c}2018 \text { рік } \\
\text { (прогноз })\end{array}$} \\
\cline { 2 - 9 } & тис. грн. & $\%$ & тис. грн. & $\%$ & тис. грн. & $\%$ & тис. грн. & $\%$ \\
\hline $\begin{array}{c}\text { Арсенал } \\
\text { страхування }\end{array}$ & 225200 & 26,62 & 295828 & 26,98 & 287128 & 21,98 & 353954 & 25,52 \\
\hline АСКА & 219962 & 26,00 & 271174 & 24,74 & 181723 & 13,91 & 75500 & 5,44 \\
\hline РZU Україна & 109579 & 12,95 & 121039 & 11,04 & 140201 & 10,73 & 128280 & 9,25 \\
\hline $\begin{array}{c}\text { АХА } \\
\text { страхування }\end{array}$ & 79227 & 9,36 & 139232 & 12,70 & 219771 & 16,82 & 239008 & 17,23 \\
\hline Інго-Україна & 70487 & 8,33 & 82393 & 7,52 & 92771 & 7,10 & 87548 & 6,31 \\
\hline Уніка & 49308 & 5,83 & 65723 & 5,99 & 305272 & 23,37 & 423614 & 30,54 \\
\hline Провідна & 48883 & 5,78 & 55855 & 5,09 & 27639 & 2,12 & 14512 & 1,05 \\
\hline Універсальна & 43490 & 5,14 & 65065 & 5,93 & 51973 & 3,98 & 64670 & 4,66 \\
\hline ЧРSК & 41464 & 4,90 & 34510 & 3,15 & 34092 & 2,61 & 37134 & 2,68 \\
\hline $\begin{array}{c}\text { Альфа } \\
\text { страхування }\end{array}$ & 32286 & 3,82 & 25313 & 2,31 & 33898 & 2,59 & 32170 & 2,32 \\
\hline $\begin{array}{c}\text { Українська } \\
\text { страхова } \\
\text { група }\end{array}$ & 31806 & 3,76 & 37637 & 3,43 & 42000 & 3,21 & 36694 & 2,65 \\
\hline Альянс & 66799 & 7,89 & 188261 & 17,17 & 221704 & 16,97 & 196388 & 14,16 \\
\hline ТАС СГ & 16665 & 1,97 & 30830 & 2,81 & 40079 & 3,07 & 30476 & 2,20 \\
\hline Загалом & 846136 & 100 & 1096309 & 100 & 1306478 & 100 & 1387086 & 100 \\
\hline Складено
\end{tabular}

Складено авторами на основі [9]

Як бачимо, ринок страхування майна є більш вільним - за досліджуваний період перелік компаній-лідерів змінювався.

Однак є компанії, які утримують домінуючі позиції протягом усього періоду 2015-2018 років - це Арсенал страхування, АХА страхування, PZU Україна, компанії, які досягли дуже значного росту за останні два роки - Уніка та Альянс, а також компанії, які фактично полишили цей сегмент ринку страхових послуг - АСКА.

Проаналізуємо наступний перспективний вид класичного страхування добровільне медичне страхування (табл. 4). 


\section{Аналіз обсягів страхових премій компаній від добровільного}

медичного страхування

\begin{tabular}{|c|c|c|c|c|c|c|c|c|}
\hline \multirow{2}{*}{$\begin{array}{c}\text { Назва страхової } \\
\text { компанії }\end{array}$} & \multicolumn{2}{|c|}{2015 рік } & \multicolumn{2}{|c|}{2016 рік } & \multicolumn{2}{c|}{2017 рік } & \multicolumn{2}{c|}{$\begin{array}{c}2018 \text { рік } \\
\text { (прогноз) }\end{array}$} \\
\cline { 2 - 10 } & тис. грн. & $\%$ & тис. грн. & $\%$ & тис. грн. & $\%$ & тис. грн. & $\%$ \\
\hline Провідна & 241069 & 20,96 & 288759 & 19,52 & 358849 & 20,75 & 457688 & 21,80 \\
\hline Нефтегазстрах & 206942 & 17,99 & 241523 & 16,33 & 252350 & 14,59 & 248706 & 11,85 \\
\hline Уніка & 155336 & 13,51 & 175681 & 11,88 & 226415 & 13,09 & 389708 & 18,56 \\
\hline $\begin{array}{c}\text { АХА } \\
\text { страхування }\end{array}$ & 122040 & 10,61 & 181798 & 12,29 & 205470 & 11,88 & 276202 & 13,16 \\
\hline РZU Україна & 98585 & 8,57 & 128832 & 8,71 & 154636 & 8,94 & 156260 & 7,44 \\
\hline Інго Україна & 94050 & 8,18 & 125498 & 8,48 & 133176 & 7,70 & 157872 & 7,52 \\
\hline $\begin{array}{c}\text { Українська } \\
\text { страхова група }\end{array}$ & 75166 & 6,54 & 88497 & 5,98 & 96008 & 5,55 & 120128 & 5,72 \\
\hline $\begin{array}{c}\text { Дім } \\
\text { страхування }\end{array}$ & 56440 & 4,91 & 22832 & 1,54 & 46413 & 2,68 & 41380 & 1,97 \\
\hline $\begin{array}{c}\text { Альфа } \\
\text { страхування }\end{array}$ & 53676 & 4,67 & 132969 & 8,99 & 124665 & 7,21 & 131576 & 6,27 \\
\hline Країна & 46837 & 4,07 & 92910 & 6,28 & 131265 & 7,59 & 119916 & 5,71 \\
\hline Загалом & 1150141 & 100 & 1479299 & 100 & 1729245 & 100 & 2099436 & 100 \\
\hline
\end{tabular}

Складено авторами на основі [9]

На ринку добровільного медичного страхування, як бачимо 3 табл. 4, також видно чіткий розподіл часток ринку між кількома основними учасниками. Домінуючими компаніями на ринку $є$ Провідна, Уніка, Нефтегазстрах, АХА страхування. Слід відзначити, що цей сегмент ринку $є$ найбільш стабільним за структурою протягом всього досліджуваного періоду.

Проаналізуємо структуру ринку страхування туристів (табл. 5).

Табличя 5

Аналіз обсягів страхових премій компаній від страхування туристів

\begin{tabular}{|c|c|c|c|c|c|c|c|c|}
\hline \multirow{2}{*}{$\begin{array}{c}\text { Назва страхової } \\
\text { компанії }\end{array}$} & \multicolumn{2}{|c|}{2015 рік } & \multicolumn{2}{c|}{2016 рік } & \multicolumn{2}{c|}{2017 рік } & \multicolumn{2}{c|}{$\begin{array}{c}2018 \text { рік } \\
\text { (прогноз }\end{array}$} \\
\cline { 2 - 9 } & $\begin{array}{c}\text { тис. } \\
\text { грн. }\end{array}$ & $\%$ & $\begin{array}{c}\text { тис. } \\
\text { грн. }\end{array}$ & $\%$ & $\begin{array}{c}\text { тис. } \\
\text { грн. }\end{array}$ & $\%$ & $\begin{array}{c}\text { тис. } \\
\text { грн. }\end{array}$ & $\%$ \\
\hline 1 & 2 & 3 & 4 & 5 & 6 & 7 & 8 & 9 \\
\hline PZU Україна & 75300 & 28,89 & 94667 & 24,11 & 110813 & 22,73 & 113124 & 22,08 \\
\hline
\end{tabular}


Продовження таблиці 5

\begin{tabular}{|c|c|c|c|c|c|c|c|c|}
\hline 1 & 2 & 3 & 4 & 5 & 6 & 7 & 8 & 9 \\
\hline $\begin{array}{c}\text { Свропейське } \\
\text { туристичне } \\
\text { страхування }\end{array}$ & 51942 & 19,93 & 78850 & 20,08 & 109889 & 22,54 & 117558 & 22,95 \\
\hline ВУСО & 35580 & 13,65 & 71317 & 18,16 & 116179 & 23,83 & 99728 & 19,47 \\
\hline Кремінь & 27991 & 10,74 & 45738 & 11,65 & 36013 & 7,39 & 49388 & 9,64 \\
\hline Княжа & 18399 & 7,06 & 24391 & 6,21 & 32462 & 6,66 & 38782 & 7,57 \\
\hline Провідна & 17526 & 6,72 & 33620 & 8,56 & 30527 & 6,26 & 28674 & 5,60 \\
\hline $\begin{array}{c}\text { АХА } \\
\text { страхування }\end{array}$ & 17140 & 6,58 & 21280 & 5,42 & 27097 & 5,56 & 37128 & 7,25 \\
\hline Перша & 16792 & 6,44 & 22821 & 5,81 & 24458 & 5,02 & 27960 & 5,46 \\
\hline ТАС СГ & 16305 & 6,26 & 30726 & 7,82 & 49468 & 10,15 & 69302 & 13,53 \\
\hline Укрфінгосстрах & 8854 & 3,40 & 26842 & 6,84 & 43827 & 8,99 & 54332 & 10,60 \\
\hline Універсальна & 14114 & 5,41 & 16255 & 4,14 & 28850 & 5,92 & 38826 & 7,58 \\
\hline Глобус & 2345 & 0,90 & 11377 & 2,90 & 16254 & 3,33 & 26398 & 5,15 \\
\hline Інго-Україна & 11633 & 4,46 & 15332 & 3,90 & 19634 & 4,03 & 23770 & 4,64 \\
\hline Загалом & 260668 & 100 & 392684 & 100 & 487437 & 100 & 512342 & 100 \\
\hline
\end{tabular}

Складено авторами на основі [9]

Ринок страхування туристів характеризується сталим ступенем розподілу ринку серед кількома ключовими гравцями, а саме компаніями PZU Україна, Європейське туристичне страхування, ВУСО, однак поширення внутрішнього та зовнішнього туризму створюють умови для виходу на ринок і для інших компаній, що можна побачити за обсягами зростання страхових премій таких компаній, як Укрфінгосстрах та ТАС СГ. Проаналізуємо розміри страхових премій від агрострахування (табл. 6).

Таблиия 6

\section{Аналіз обсягів страхових премій компаній від агрострахування}

\begin{tabular}{|c|c|c|c|c|c|c|c|c|}
\hline \multirow{2}{*}{$\begin{array}{c}\text { Назва } \\
\text { страхової } \\
\text { компанії }\end{array}$} & \multicolumn{2}{|c|}{2015 рік } & \multicolumn{2}{|c|}{2016 рік } & \multicolumn{2}{|c|}{2017 рік } & \multicolumn{2}{|c|}{$\begin{array}{c}2018 \text { рік } \\
\text { (прогоз })\end{array}$} \\
\cline { 2 - 9 } & тис. грн. & $\%$ & $\begin{array}{c}\text { тис. } \\
\text { грн. }\end{array}$ & $\%$ & $\begin{array}{c}\text { тис. } \\
\text { грн. }\end{array}$ & $\%$ & $\begin{array}{c}\text { тис. } \\
\text { грн. }\end{array}$ & $\%$ \\
\hline 1 & 2 & 3 & 4 & 5 & 6 & 7 & 8 & 9 \\
\hline Універсальна & 6146 & 7,76 & 27622 & 17,27 & 129847 & 54,98 & 127352 & 51,20 \\
\hline РZU Україна & 22791 & 28,77 & 40060 & 25,05 & 41199 & 17,44 & 54164 & 21,78 \\
\hline АСКА & 16805 & 21,22 & 49154 & 30,73 & 9243 & 3,91 & 21956 & 8,83 \\
\hline $\begin{array}{c}\text { AХА } \\
\text { страхування }\end{array}$ & 8757 & 11,06 & 4663 & 2,92 & 8557 & 3,62 & 16102 & 6,47 \\
\hline
\end{tabular}


Продовження таблиці 6

\begin{tabular}{|c|c|c|c|c|c|c|c|c|}
\hline 1 & 2 & 3 & 4 & 5 & 6 & 7 & 8 & 9 \\
\hline Інго Україна & 22097 & 27,90 & 21623 & 13,52 & 20694 & 8,76 & 16098 & 6,47 \\
\hline Брокбізнес & 1843 & 2,33 & 3926 & 2,45 & 5764 & 2,44 & 8546 & 3,44 \\
\hline Країна & 773 & 0,98 & 12892 & 8,06 & 20882 & 8,84 & 4522 & 1,82 \\
\hline ТАС СГ & 612 & 0,77 & 540 & 0,34 & 687 & 0,29 & 2278 & 0,92 \\
\hline UРSK & 1512 & 1,91 & 362 & 0,23 & 935 & 0,40 & 1442 & 0,58 \\
\hline $\begin{array}{c}\text { Українська } \\
\begin{array}{c}\text { аграрно- } \\
\text { страхова } \\
\text { компанія }\end{array}\end{array}$ & 5401 & 6,82 & 10001 & 6,25 & 12007 & 5,08 & & \\
\hline $\begin{array}{c}\text { Арсенал } \\
\text { страхування }\end{array}$ & 84 & 0,11 & 53004 & 33,14 & 2555 & 1,08 & 54 & 0,02 \\
\hline Провідна & 898 & 1,13 & 799 & 0,50 & 616 & 0,26 & 424 & 0,17 \\
\hline Здорово & 51904 & 65,53 & 4870 & 3,04 & & & & \\
\hline Загалом & 79210 & 100 & 159940 & 100 & 236186 & 100 & 248740 & 100 \\
\hline
\end{tabular}

Складено авторами на основі [9]

Ситуація на ринку агрострахування, як бачимо з табл. 6, дуже нестабільна - деякі компанії лідери на початку досліджуваного періоду фактично пішли 3 ринку (АСКА, Інго Україна, Здорово), однак незмінними лідерами є компанії Універсальна та PZU Україна. Така ситуація пов'язана 3 високим рівнем нестабільності та неконтрольованого ризику саме в цьому виді класичного страхування.

Висновки 3 проведеного дослідження. Як бачимо, головною рисою страхового ринку України є чітка спеціалізація компаній на певних видах класичного страхування, що приводить до значних труднощів при виході на ринок нових компаній або при спробі поширення діяльності на інші класичні види страхування. Тобто головним інструментом для досягнення означених цілей насьогодні є розвиток нових видів добровільного страхування.

\section{Перелік посилань}

1. Базилевич В. Д., Базилевич К. С., Пікус Р. В. Страхування: підручник. Київ: Знання, 2008. 648 с.

2. Базилевич В. Д., Пікус Р. В., Приказюк Н. В., Моташко Т. П. Страхові послуги: підручник у 2 ч. Ч. 2. К.: Логос, 2014. 527 с. 
3. Cummins J. D., Doherty N. A. The economics of insurance intermediaries. Journal of Risk and Insurance. 2007. № 73. C. 347-349.

4. Любашенко I. Обов'язкове страхування цивільної відповідальності автовласників в Україні та Росії. Міфи та реальність. Страхова справа. 2004. №13. C. 46-51.

5. Ротова Т. Методичний інструментарій управління страховими ризиками. Фінанси України. 2002. №3. С. 122-128.

6. Фисун В. І., Ярова Г. М. Страхування: навч. посіб. Київ: Центр учбової літератури, 2011. 232 с.

7. Прилипко С. М., Ярошенко О. М., Занфірова Т. А., Аркатов Я. А. Загальнообов'язкове державне соціальне медичне страхування в Україні: сучасний стан та стратегія розвитку: монографія. Харків, 2017. 208 с.

8. Білик О. І., Качмарчик С. А. Переваги та недоліки введення обов'язкової форми медичного страхування в Україні. Вісник Національного університету «Львівська політехніка». 2013. № 767. С. 270-277.

9. Рейтинг страховых компаний Украины. Фориншурер страхование : сайт. URL : https://forinsurer.com/ratings/nonlife (дата звернення : 28.11.2018).

10. Закон України "Про страхування" №2288-IV із змінами від 23.12.04. Відомості Верховної Ради. 2005. №6. С.138.

\section{References}

1. Bazylevych, V., Bazylevych, K., Pikus, R. (2008), Insurance: textbook [Strakhuvannia: pidruchnyk], Znannia, Kyiv, 648 p.

2. Bazylevych, V., Pikus, R., Prykaziuk, N., Motashko, T. (2014), Insurance services: textbook [Strakhovi posluhy: pidruchnyk], Lohos, Kyiv, 527 p.

3. Cummins, J., Doherty, N. (2007), "The economics of insurance intermediaries". Journal of Risk and Insurance, No 73, P. 347-349.

4. Liubashenko, I. (2004), "Obligatory insurance of civil liability of car owners in Ukraine and Russia. Myths and reality" ["Oboviazkove strakhuvannia tsyvilnoi vidpovidalnosti avtovlasnykiv $\mathrm{v}$ Ukraini ta Rosii. Mify ta realnist"], Insurance business, No. 13, P. 46-51. 
5. Rotova, T. (2002), "Methodological tools for insurance risk management" ["Metodychnyi instrumentarii upravlinnia strakhovymy ryzykamy"], Finance of Ukraine, No. 3, P. 122-128.

6. Fysun, V., Yarova, H. (2011), Insurance. Teaching manual [Strakhuvannia. Navch. posib.], Center of educational literature, Kyiv, 232 p.

7. Prylypko, S., Yaroshenko, O., Zanfirova, T., Arkatov, Ya. (2017), Obligatory State Social Health Insurance in Ukraine: Current State and Development Strategy: monograph [Zahalnooboviazkove derzhavne sotsialne medychne strakhuvannia $v$ Ukraini: suchasnyi stan ta stratehiia rozvytku: monohrafiia], Kharkiv, 208 p.

8. Bilyk, O., Kachmarchyk, S. (2013), "Advantages and disadvantages of introducing compulsory medical insurance in Ukraine" ["Perevahy ta nedoliky vvedennia oboviazkovoi formy medychnoho strakhuvannia v Ukraini"], Bulletin of Lviv Polytechnic National University, No. 767, P. 270-277.

9. Rating of insurance companies of Ukraine [Reitynh strakhovykh kompanyi Ukrayny. Forynshurer strakhovanye], available at https://forinsurer.com/ratings/nonlife (last accessed 28.11.2018).

10. The Law of Ukraine "On insurance" №2288-IV as amended on 12.23.04 [Zakon Ukrainy "Pro strakhuvannia" No. 2288-IV iz zminamy vid 23.12.04], Information from the Verkhovna Rada, 2005, No. 6, P.138.

\section{РЕФЕРАТИ РЕФЕРАТЫ ABSTRACTS}

\section{УДК 368; JEL CLASSIFICATION: G 220}

Онісіфорова В.Ю., Болотова Т.М., Остапенко Л.О. АНАЛІЗ РИНКУ СТРАХОВИХ ПОСЛУГ УКРАЇНИ

Мета. Визначення основних характеристик ринку класичних видів страхування в сучасних умовах України. Методика дослідження. В ході дослідження використовувалися методи аналізу і синтезу, метод логічного аналізу. Інформаційними ресурсами дослідження є електронні інформаційні ресурси і матеріали періодичних видань. Результати. Ринок страхових послуг в Україні характеризується високим рівнем конкуренції, однак перед компаніями, що створюються, а також перед існуючими страховими компаніями, не зважаючи на це, стоїть задача поширення масштабів діяльності 
шляхом виходу на нові ринки, а також на нові види страхування. Основні закономірності функціонування страхового ринку України можна побачити після проведення грунтовного аналізу показників галузі за головними найпоширенішими видами страхування. Ринок страхування цивільно-правової відповідальності власників наземних транспортних засобів характеризується позитивною динамікою обсягів зібраних страхових премій, однак на ринку $є$ група компаній, які $є$ утримувачами переважного сегменту даного ринку, i протягом досліджуваного періоду 2015-2018 років ці компанії лише укріплюють своє положення на ринку. Такими компаніями є Оранта, Провідна, TAC СГ, UPSK. Ринок КАСКО $є$ ще більш утримуваним певним колом компаній-лідерів. За даними досліджуваного періоду можна виділити три страхових компанії, які фактично утримують даний ринок - це АХА страхування, Уніка, Українська страхова група, а також останніми роками укріплює свої позиції на ринку КАСКО компанія Арсенал страхування. Ринок страхування майна $\epsilon$ більш вільним. Однак $\epsilon$ компанії, які утримують домінуючі позиції протягом усього періоду 2015-2018 років - це Арсенал страхування, AXA страхування, PZU Україна, компанії, які досягли дуже значного росту за останні два роки - Уніка та Альянс, а також компанії, які фактично полишили цей сегмент ринку страхових послуг - ACКА. На ринку добровільного медичного страхування також видно чіткий розподіл часток ринку між кількома основними учасниками - це компанії Провідна, Уніка, Нефтегазстрах, АХА страхування. Слід відзначити, що цей сегмент ринку є найбільш стабільним за структурою протягом всього досліджуваного періоду. Ринок страхування туристів характеризується сталим ступенем розподілу ринку серед кількома ключовими гравцями, а саме компаніями PZU Україна, Європейське туристичне страхування, ВУСО, однак можна побачити зростання часток компаній Укрфінгосстрах та ТАC СГ. Ситуація на ринку агрострахування дуже нестабільна - деякі компанії- фактично пішли з ринку (АСКА, Інго Україна, Здорово), однак незмінними лідерами $є$ компанії Універсальна та PZU Україна. Головною рисою страхового ринку України $є$ чітка спеціалізація компаній на певних видах класичного страхування, що приводить до значних труднощів при виході на ринок нових компаній або при спробі поширення діяльності на інші класичні види страхування. Тобто головним інструментом для досягнення означених цілей насьогодні $є$ розвиток нових видів добровільного страхування. Наукова новизна. Визначено перспективи виходу компаній на ринки основних класичних видів страхування. Практична значущість. Запропоновані висновки можуть бути використані дослідниками та керівниками страхових компаній при визначенні перспектив виходу на нові ринки класичних видів страхування.

Ключові слова: страхування; страхові премії; страховий ринок; лідери страхового ринку; структура страхового ринку.

УДК 368; JEL Classification: G 220

\section{Онисифорова В.Ю., Болотова Т.Н., Остапенко Л.А. АНАЛИЗ РЫНКА СТРАХОВЫХ УСЛУГ УКРАИНЫ}


Цель. Определение основных характеристик рынка классических видов страхования в современных условиях Украины. Методика исследования. В ходе исследования использовались методы анализа и синтеза, метод логического анализа. Информационными ресурсами исследования являются электронные информационные ресурсы и материалы периодических изданий. Pезультаты. Рынок страховых услуг в Украине характеризуется высоким уровнем конкуренции, однако перед создаваемыми компаниями, а также перед существующими страховыми компаниями, несмотря на это, стоит задача распространения масштабов деятельности путем выхода на новые рынки, а также на новые виды страхования. Основные закономерности функционирования страхового рынка Украины можно увидеть после проведения тщательного анализа показателей отрасли по главным самым распространенным видам страхования. Рынок страхования гражданскоправовой ответственности владельцев наземных транспортных средств характеризуется положительной динамикой объемов собранных страховых премий, однако на рынке есть группа компаний, являющихся держателями преимущественного сегмента данного рынка, и в течении исследуемого периода 2015-2018 годов эти компании только укрепляют свое положение на рынке. Такими компаниями являются Оранта, Провидна, ТАС СГ, UPSK. Рынок КАСКО удерживается определенным кругом компаний-лидеров. По данным исследуемого периода можно выделить три страховых компании, которые фактически содержат данный рынок - это АХА страхование, Уника, Украинская страховая группа, а также в последние годы укрепляет свои позиции на рынке КАСКО компания Арсенал страхование. Рынок страхования имущества более свободный. Однако есть компании, которые удерживают доминирующие позиции в течение всего периода 2015-2018 годов - это Арсенал страхование, AXA страхование, PZU Украина, компании, достигли значительного роста за последние два года - Уника и Альянс, а также компании, которые фактически оставили этот сегмент рынка страховых услуг АСКА. На рынке добровольного медицинского страхования также видно четкое распределение долей рынка между несколькими основными участниками - это компании Провидна, Уника, Нефтегазстрах, АХА страхование. Следует отметить, что этот сегмент рынка является наиболее стабильным по структуре в течении всего исследуемого периода. Рынок страхования туристов характеризуется постоянной степенью распределения рынка среди несколькими ключевыми игроками, а именно компаниями PZU Украина, Европейское туристическое страхование, ВУСО, однако можно увидеть рост долей компаний Укрфингосстрах и ТАС СГ. Ситуация на рынке агрострахования очень нестабильна - некоторые компании-фактически ушли с рынка (АСКА, Инго Украина, Здорово), однако неизменными лидерами являются компании Универсальная и PZU Украина. Главной чертой страхового рынка Украины является четкая специализация компаний на определенных видах классического страхования, что приводит к значительным трудностям при выходе на рынок новых компаний или при попытке распространения деятельности на другие классические виды страхования. То есть главным 
инструментом для достижения указанных целей сегодня является развитие новых видов добровольного страхования Научная новизна. Определены перспективы выхода компаний на рынки основных классических видов страхования. Практическая значимость. Предложенные выводы могут быть использованы исследователями и руководителями страховых компаний при определении перспектив выхода на новые рынки классических видов страхования.

Ключевые слова: страхование; страховые премии; страховой рынок; лидеры страхового рынка; структура страхового рынка.

\section{UDC 368; JEL Classification: G 220}

Onisiforova V.Yu., Bolotova T.M., Ostapenko L.O. ANALYSIS OF THE MARKET OF INSURANCE SERVICES OF UKRAINE

Purpose. The determination of the basic characteristics of the market of classical types of insurance in the modern conditions of Ukraine. Methodology of research. During the study, methods of analysis and synthesis, method of logical analysis were used. Information resources of the research are electronic information resources and periodical material. Findings. The insurance market in Ukraine is characterized by a high level of competition, but despite the existing companies and existing insurance companies, the task of expanding the scope of activities is to open up new markets as well as new types of insurance. The main regularities of the functioning of Ukrainian insurance market can be seen after a thorough analysis of industry indicators by the main most common types of insurance. The insurance market for civil liability of land vehicle owners is characterized by a positive dynamics of the volume of collected insurance premiums, but there group of companies that are holders of the prevailing segment of this market and during the investigated period of 2015-2018, these companies were strengthening their position in the market. Such companies are Oranta, Providna, TAS AG, UPSK. CASCO market is even more kept by certain leading companies. According to the survey period, there are three insurance companies that actually hold this market - AXA insurance, Unika, Ukrainian insurance group, and in recent years strengthened its position in the CASCO insurance the company Arsenal insurance. The property insurance market is more free. However, there are companies that were holding a dominant position throughout the 2015-2018 period - the insurance Arsenal, AXA insurance, PZU Ukraine. These companies have achieved very strong growth over the past two years - Unica and Alliance, as well as companies that have actually left this Insurance market segment - ASKA. The market for voluntary health insurance also shows a clear distribution of market partsbetween several key players - such as Providna, Unika, Neftegazstrakh, AXA insurance. It should be noted that this segment of the market is the most stable in structure over the entire period under study. The insurance market for tourists is characterized by a steady distribution of the market between several key players, namely PZU Ukraine, European Travel Insurance, VUSO, but the growth of the parts of Ukrfingosstrakh and TAS IG can be seen. The situation on the agro-insurance market is very unstable - some companies have actually left the market (ASKA, Ingo Ukraine, Zdorovo), but the unchanged 
leaders are Universal and PZU Ukraine. The main feature of the insurance market in Ukraine is a clear specialization of companies in certain types of classical insurance. This leads to significant difficulties when entering new companies' markets or when attempting to extend activities to other classic types of insurance. That is, the development of new types of voluntary insurance is the main instrument for achieving the stated goals today. Originality. The prospects of the company's entering into the markets of the main classic types of insurance are determined. Practical value. The proposed conclusions can be used by researchers and managers of insurance companies for determining the prospects of entering new markets for classic types of insurance.

Key words: insurance; insurance premiums; insurance market; leaders of the insurance market; structure of the insurance market.

\section{Відомості про авторів / Сведения об авторах / About the Authors}

Онісіфорова Валентина Юріївна - кандидат економічних наук, доцент, Харківський національний автомобільно-дорожній університет, доцент кафедри економіки i підприємництва, м. Харків, Україна; e-mail: valentinaonisiforova @ gmail.com; ORCID ID: http://orcid.org/0000-0001-9899-8427. Моб. 099-499-14-28.

Онисифорова Валентина Юрьевна - кандидат экономических наук, доцент, Харьковский национальный автомобильно-дорожный университет, доцент кафедры экономики и предпринимательства, г. Харьков, Украина.

Onisiforova Valentyna - Candidate of Sciences (Economics), Associate Professor, Kharkov National Automobile and Highway University, Associate Professor at the Department of Economics and Entrepreneurship, Kharkiv, Ukraine.

Болотова Тетяна Миколаївна - кандидат економічних наук, доцент, Харківський торговельно-економічний коледж КНТЕУ, завідувач ЦК економіки та маркетингу, м. Харків, Україна; e-mail: tatabolotova1975@gmail.com; ORCID ID: http://orcid.org/0000-0003-1414-880X. Моб. (050)302-57-77.

Болотова Татьяна Николаевна - кандидат экономических наук, доцент, Харьковский торгово-экономический колледж КНТЭУ, заведующая ЦК экономики и маркетинга, г. Харьков, Украина.

Bolotova Tatyana - Candidate of Sciences (Economics), Kharkov College of Trade and Economics KNTEU, head of the Central Committee of Economics and Marketing, Kharkiv, Ukraine.

Остапенко Леонід Олександрович - Харківський національний автомобільно-дорожній університет, студент, м. Харків, Україна; e-mail: leoauto14@gmail.com. Моб.097-753-07-98.

Остапенко Леонид Александрович - Харьковский национальный автомобильно-дорожный университет, студент, г. Харьков, Украина.

Ostapenko Leonid Oleksandrovych - Kharkov National Automobile and Highway University, student, Kharkiv, Ukraine. 